OPEN ACCESS

Edited by:

Offer Erez,

Soroka Medical Center, Israel

Reviewed by:

Kazumichi Fujioka,

Kobe University, Japan

MaryAnn Volpe,

Tufts University School of Medicine,

United States

*Correspondence:

Dongchi Zhao

zhaodongchi@znhospital.cn

Specialty section:

This article was submitted to

Neonatology,

a section of the journal

Frontiers in Pediatrics

Received: 18 March 2020

Accepted: 12 June 2020

Published: 28 July 2020

Citation:

Liao L, Deng Y and Zhao D (2020)

Association of Low Birth Weight and

Premature Birth With the Risk of

Metabolic Syndrome: A

Meta-Analysis. Front. Pediatr. 8:405.

doi: 10.3389/fped.2020.00405

\section{Association of Low Birth Weight and Premature Birth With the Risk of Metabolic Syndrome: A Meta-Analysis}

\author{
Lihong Liao, Youping Deng and Dongchi Zhao* \\ Department of Pediatrics, Zhongnan Hospital of Wuhan University, Wuhan University, Wuhan, China
}

The association of preterm or low birth weight (LBW) with the risk of metabolic syndrome is still unclear. This study aimed to assess the association between preterm or LBW and metabolic syndrome risk according to study or participants' characteristics. PubMed, Web of Science, and EMBASE were searched for epidemiologic studies on the association published up to April 30, 2020. Pooled odds ratio (ORs) and weighted mean differences (WMDs) with 95\% confidence intervals (Cls) were calculated using the random-effects model. Low birth weight was associated with an increased risk of metabolic syndrome (OR, 1.37; 95\% Cl, 1.17-1.61). In the subgroup analysis by study design, the pooled ORs for LBW and metabolic syndrome in the cohort and cross-sectional studies were 1.79 and 1.22. In the subgroup analysis by sex, LBW was found to be associated with an increased risk of metabolic syndrome in pooled studies including both men and women or studies including only women. The association between premature birth and risk of metabolic syndrome was significant in cohort studies (OR, 1.72; 95\% Cl, 1.12-2.65). Also, LBW or preterm was significantly associated with a higher Homeostasis Model Assessment of Insulin Resistance (WMD, 0.28; 95\% Cl, 0.19-0.36). Low birth weight and preterm might be risk factors for metabolic syndrome.

Keywords: low birth weight, meta-analysis, metabolic syndrome, premature birth, preterm

\section{INTRODUCTION}

Metabolic syndrome is defined as a cluster of any three or more of these features: elevated waist circumference, elevated triglyceride level, reduced high-density lipoprotein cholesterol level, elevated blood pressure, elevated fasting glucose level (1-3), and insulin resistance is the pathogenesis $(4,5)$. The median prevalence of metabolic syndrome in the whole population was $3.3 \%$, which ranged from 0 to $19.2 \%$ (6). Previous studies found that a cluster of symptoms of metabolic syndrome was associated with various chronic diseases, including cardiovascular disease, type 2 diabetes mellitus, and cancer at various sites (7-9). Therefore, clarifying the independent risk factors for metabolic syndrome is particularly important in the general population.

Several epidemiological studies were conducted to look for the cause of metabolic syndrome. Many dietary, behavioral, and psychological factors have been confirmed to be associated with metabolic syndrome, such as sugar-sweetened and artificially sweetened beverage intake (10), low levels of physical activity and sedentary behavior (11), and anxiety (12). In recent years, many studies found an association of several perinatal risk factors, such as low birth weight 
(LBW) and premature birth, with the increased risk of metabolic syndrome, but some others showed contradictory results (1327). Therefore, this meta-analysis was conducted to evaluate the association of LBW and premature birth with metabolic syndrome. Moreover, the stratified analyses according to study design, sex, and continent were also illustrated.

\section{MATERIALS AND METHODS}

This meta-analysis was performed following the Preferred Reporting Items for Systematic Reviews and Meta-Analysis Statement Checklist (28).

\section{Literature Search Strategy}

The databases PubMed, Web of Science, and EMBASE up to April 30, 2020, were searched, using the following terms: [(prematurity) OR (premature birth) OR (premature infant) OR (low birth weight) OR (preterm)] AND [(metabolic syndrome) OR (metabolic syndrome, components) OR (hypertension) OR (high blood pressure) OR (insulin resistance) OR (glucose intolerance) OR (obesity) OR (overweight) OR (fat mass) OR (dyslipidemia) OR (hypercholesterolemia), as text words or Medical Subject Heading terms. In addition, the reference lists of the included studies were reviewed for undetected relevant studies.

\section{Inclusion Criteria}

The details of inclusion criteria were as follows: (1) study design: the study was original research from observational studies; (2) participants: general population; (3) exposure: LBW or premature birth; (4) comparator: normal birth weight or full-term birth; and (5) outcome: metabolic syndrome. The most recent and complete study was selected if data from the same population had been published repeatedly. The exclusion criteria were as follows: review, comments, animal experiments, patients diagnosed with other diseases, and studies that did not report the effect estimates between LBW or preterm and metabolic syndrome.

All identified studies were searched and reviewed by three investigators (L.L.H., D.Y.P., and Z.D.C.) independently. Disagreements on the eligibility of a study were resolved by consensus by the primary author (Z.D.C.) referring to the original article.

\section{Data Extraction and Quality Assessment}

Data extraction from each study by two investigators independently included the first author's name, publication year, country where the study was conducted, study design, age, sample size, and number of cases, perinatal risk factors (LBW or premature birth), odds ratio (OR), or hazard ratio (all results were presented as OR owing to this study designed as cohort) with $95 \%$ confidence interval (CI), definition of metabolic syndrome, adjustment for potential confounding factors, cutoff value of LBW and preterm, and Homeostasis Model Assessment of Insulin Resistance (HOMA-IR). For studies that reported several multivariate adjusted ORs, the effect estimate that was maximally adjusted for potential confounders was selected. The study quality was assessed using the Newcastle-Ottawa Scale (NOS), which was based on selection (four items), comparability (one item), and outcome (three items), with a total of 0-9 stars (29).

\section{Statistical Analysis}

The association of LBW or preterm with the risk of metabolic syndrome was assigned as categorical data, and OR with its 95\% CI was calculated in an individual study before data pooling. Moreover, the potential association of LBW or preterm with HOMA-IR was assigned as a weighted mean difference (WMD) with $95 \%$ CI. All of the pooled analyses were carried out using the random-effects model because of underlying variations among included studies (30). The $I^{2}$ - and $P$-value for $\mathrm{Q}$ statistic were used to test the heterogeneity between the included studies $\left(I^{2}\right.$ values of $0,25,50$, and $75 \%$ represented no, low, moderate, and high heterogeneity, respectively), and $P<0.10$ was considered as significant heterogeneity (31). A univariate metaregression analysis was carried out to explore the potential sources of study heterogeneity (32). Subgroup analyses were performed by study design, sex, and continent where the studies were conducted, and the differences between subgroups were calculated using the interaction $P$-value, which was based on the $t$-test because of a lower number of included studies (33). An influence analysis was performed with one study removed at a time to assess the stability of the results (34). Publication bias was assessed with a visual inspection of the funnel plot and Egger test (35). The NOS was used to assess the quality of included studies (36).

All statistical analyses were performed using Stata 14.0 (StataCorp, College Station, TX, USA). All reported probabilities ( $P$-values) were two-sided with a statistical significance level of 0.05 .

\section{RESULTS}

\section{Literature Search and Study Characteristics}

The search process is shown in Figure 1. A total of 4,821 articles were identified through the literature search. Three additional articles were found from the reference lists of the included articles. A total of 700 articles were excluded owing to duplicate topics. Moreover, 4,095 articles were excluded after reviewing the titles and abstracts. After reviewing full-text articles, seven articles without OR and/or 95\% CI, four articles without relevant outcome, and three reviews were excluded. Finally, 15 published articles with 16 studies were included in this meta-analysis (13-27). All but two studies $(20,27)$ scored 7 points, and the remaining studies scored 5 or 6 points (Table 1).

\section{Characteristics of Studies}

For the association between LBW and the risk of metabolic syndrome, 10 articles $(13-16,18,21-23,25,26)$ with 11 studies ( involving 16,693 participants. Among these studies, three were conducted in Asia, five in Europe, and two in South America. Seven studies focused on women and men, two only on men, and two only on women. For the association between premature birth 


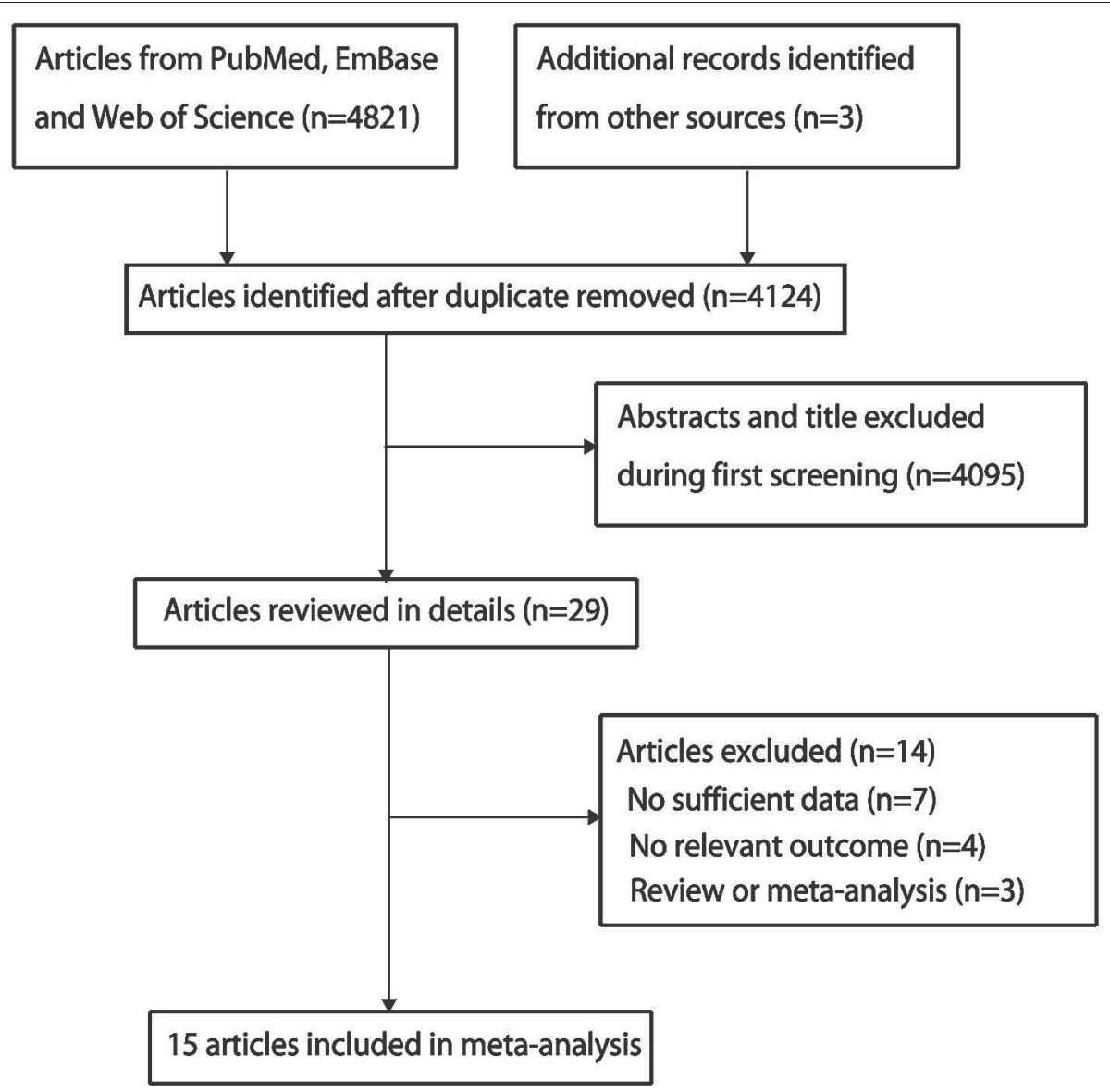

FIGURE 1 | Flowchart of the selection of studies included in the meta-analysis.

and the risk of metabolic syndrome, five articles (19, 20, 23, 24, 27 ) with five studies (four cohort studies and one cross-sectional study) were included, involving 7,295 participants. Among these studies, one was conducted in Europe, two in South America, one in North America, and one in Oceania. Four studies focused on women and men, and the remaining one study only on women. All of the included studies reported OR as an effect estimate, excluding the study conducted by Catov et al. (27). The detailed characteristics of the included studies are shown in Table $\mathbf{1 .}$

\section{Quantitative Synthesis}

The pooled results of the association of LBW and premature birth with the risk of metabolic syndrome are summarized in Table 2.

The pooled results suggested that LBW (OR $=1.37 ; 95 \%$ CI, $1.17-1.61 ; I^{2}=43.6 \%$; $P_{\text {heterogeneity }}=0.060$, Figure 2$)$ was significantly associated with the risk of metabolic syndrome. In a subgroup analysis stratified by the study design, the pooled OR of cohort studies was 1.79 (95\% CI, 1.39-2.31), with no evidence of heterogeneity $\left(I^{2}=0.0 \%\right.$; $\left.P_{\text {heterogeneity }}=0.712\right)$, and the pooled OR of cross-sectional studies was 1.22 (95\% CI, $1.04-1.43 ; I^{2}=46.1 \%$; $P_{\text {heterogeneity }}=0.115$ ) (Figure 2). In the subgroup analysis stratified by continent, a significant association was found in every continent: Asia $(\mathrm{OR}=1.66$; 95\% CI, $1.21-$ 2.29; $\left.I^{2}=0.0 \% ; P_{\text {heterogeneity }}=0.817\right)$, Europe $(\mathrm{OR}=1.69$; $95 \%$ CI, $1.23-2.33 ; I^{2}=23.7 \%$; $\left.P_{\text {heterogeneity }}=0.263\right)$, and South America $\left(\mathrm{OR}=1.18 ; 95 \% \mathrm{CI}, 1.00-1.39 ; I^{2}=55.9 \%\right.$; $P_{\text {heterogeneity }}$ $=0.104)$. Significant associations were found in studies including men and women $\left(\mathrm{OR}=1.37 ; 95 \% \mathrm{CI}, 1.04-1.79 ; I^{2}=35.0 \%\right.$; $\left.P_{\text {heterogeneity }}=0.161\right)$, as well as women only (OR $=1.39 ; 95 \%$ CI, $1.06-1.83 ; I^{2}=50.7 \%$; $\left.P_{\text {heterogeneity }}=0.154\right)$, but not in men $\left(\mathrm{OR}=1.59 ; 95 \% \mathrm{CI}, 0.58-4.38 ; I^{2}=79.7 \%\right.$; $P_{\text {heterogeneity }}$ $=0.026)$. The interaction test suggested that the study design and continent biased the association between LBW and metabolic syndrome. The pooled OR showed a non-significant positive association between premature birth and metabolic syndrome $\left(\mathrm{OR}=1.60 ; 95 \% \mathrm{CI}, 1.00-2.21 ; I^{2}=62.5 \% ; P_{\text {heterogeneity }}=\right.$ 0.030 , Figure 3 ). In the subgroup analysis stratified by the study design, the pooled OR of cohort studies was 1.72 (95\% CI, 1.12$2.65)$, with reduced heterogeneity $\left(I^{2}=54.5 \%\right.$; $P_{\text {heterogeneity }}=$ $0.086)$. Moreover, the association between preterm and metabolic syndrome differed according to the study design. Finally, the pooled WMD indicated that LBW or preterm was associated with the higher level of HOMA-IR (WMD, 0.28; 95\% CI =0.19-0.36; $I^{2}=55.6 \% ; P_{\text {heterogeneity }}=0.061$, Figure 4$)$. 
TABLE 1 | Detailed characteristics of the included studies.

\begin{tabular}{|c|c|c|c|c|c|c|c|c|c|c|c|}
\hline References & $\begin{array}{l}\text { Country } \\
\text { (year) }\end{array}$ & $\begin{array}{c}\text { Age } \\
\text { (years) }\end{array}$ & $\begin{array}{l}\text { Sex } \\
\text { (male/female) }\end{array}$ & Study design & $\begin{array}{l}\text { Participants } \\
\text { (cases) }\end{array}$ & $\begin{array}{l}\text { Perinatal } \\
\text { risk factors }\end{array}$ & $\begin{array}{l}\text { OR or RR } \\
(95 \% \mathrm{Cl})\end{array}$ & Definition of metabolic syndrome & Adjustment for covariates & $\begin{array}{l}\text { Cutoff } \\
\text { value }\end{array}$ & NOS \\
\hline Mi et al. (17) & $\begin{array}{l}\text { China } \\
(2004)\end{array}$ & $46.5 \pm 2.2$ & $\begin{array}{l}\text { Both } \\
(494 / 481)\end{array}$ & Cohort & $\begin{array}{c}975 \\
(180)\end{array}$ & LBW & $\begin{array}{l}\text { OR, } 1.98 \\
(0.69-5.73)\end{array}$ & $\begin{array}{l}\text { IFG or diabetes, and presence of at least two of } \\
\text { the following: abdominal obesity, dyslipidemia, } \\
\text { or hypertension }\end{array}$ & $\begin{array}{l}\text { Age, sex, smoking, drink, and } \\
\text { gestational age }\end{array}$ & $<\mathrm{P}_{25}$ & 5 \\
\hline $\begin{array}{l}\text { Wang et al. } \\
\text { (19) }\end{array}$ & $\begin{array}{l}\text { China } \\
(2016)\end{array}$ & $7-17$ & $\begin{array}{l}\text { Both } \\
(857 / 913)\end{array}$ & Cross-sectional & $\begin{array}{c}1,770 \\
(19)\end{array}$ & LBW & $\begin{array}{c}\text { OR, } 0.94 \\
(0.12-7.18)\end{array}$ & $\begin{array}{l}\text { Abdominal obesity and the presence of two or } \\
\text { more clinical features, including TAG } \geq 1.7 \\
\mathrm{mmol} / /, \mathrm{HDL}-\mathrm{C}<1.03 \mathrm{mmol} / \mathrm{L}, \text { blood pressure } \\
\geq 130 / 85 \mathrm{~mm} \mathrm{Hg} \text {, and serum } \mathrm{FG} \geq 5.6 \mathrm{mmol} / \mathrm{L} \text {. } \\
\mathrm{LBW} \text { and } \mathrm{HBW} \text { were defined as birth weight } \\
<2,500 \mathrm{~g} \text { and } \geq 4,000 \mathrm{~g} \text {, respectively, for } \\
\text { newborns on term without congenital } \\
\text { malformations }\end{array}$ & Sex and age & $2.5 \mathrm{~kg}$ & 6 \\
\hline $\begin{array}{l}\text { Ramadhani } \\
\text { et al. (23) }\end{array}$ & $\begin{array}{l}\text { Netherlands } \\
(2006)\end{array}$ & 28.4 (mean) & $\begin{array}{l}\text { Both } \\
(348 / 396)\end{array}$ & Cohort & $\begin{array}{l}722 \\
(68)\end{array}$ & LBW & $\begin{array}{c}\text { OR, } 1.80 \\
(1.00-3.50)\end{array}$ & $\begin{array}{l}\text { Clustering of three or more of these features: } \\
\text { WC }>102 \mathrm{~cm} \text { for men or }>88 \mathrm{~cm} \text { for women, } \\
\text { serum triglycerides } \geq 150 \mathrm{mg} / \mathrm{dL} \text {, serum } \mathrm{HDL}-\mathrm{C} \\
<40 \mathrm{mg} / \mathrm{dL} \text { for men or }<50 \mathrm{mg} / \mathrm{dL} \text { for women, } \\
\text { blood pressure } \geq 130 / 85 \mathrm{~mm} \mathrm{Hg} \text {, and serum } \\
\text { glucose } \geq 110 \mathrm{mg} / \mathrm{dL}\end{array}$ & $\begin{array}{l}\text { Sex, family history of CVD, and } \\
\text { participant's education }\end{array}$ & $3.2 \mathrm{~kg}$ & 6 \\
\hline $\begin{array}{l}\text { Laaksonen } \\
\text { et al. (22) }\end{array}$ & $\begin{array}{l}\text { Finland } \\
\text { (2003) }\end{array}$ & $\begin{array}{l}\text { Exposed: } \\
51.6 \pm 6.4 \\
\text { unexposed: } \\
50.4 \pm 6.4\end{array}$ & Male $(462 / 0)$ & Cohort & $\begin{array}{l}462 \\
(83)\end{array}$ & LBW & $\begin{array}{c}\text { OR, } 2.70 \\
(1.37- \\
5.34)\end{array}$ & $\begin{array}{l}\text { Insulin resistance in the top } 25 \% \text { of the } \\
\text { non-diabetic population, IFG or diabetes, and } \\
\text { presence of at least two of the following: } \\
\text { abdominal obesity, dyslipidemia, or } \\
\text { hypertension }\end{array}$ & Age and adult BMI & $3.4 \mathrm{~kg}$ & 6 \\
\hline $\begin{array}{l}\text { Hirschler et al. } \\
\text { (15) }\end{array}$ & $\begin{array}{l}\text { Argentina } \\
\text { (2008) }\end{array}$ & $9.4 \pm 2.1$ & $\begin{array}{l}\text { Both } \\
(511 / 516)\end{array}$ & Cross-sectional & $\begin{array}{c}1,027 \\
(35)\end{array}$ & LBW & $\begin{array}{l}\text { OR, } 1.06 \\
(0.90-1.25)\end{array}$ & $\begin{array}{l}\text { Presence of } \geq 3 \text { of the following five conditions: } \\
\text { abdominal obesity; fasting triglycerides }>110 \\
\mathrm{mg} / \mathrm{dL} ; \mathrm{HDL}-\mathrm{C}<40 \mathrm{mg} / \mathrm{dL} \text {; blood pressure } \\
>90 \text { th percentile for age, sex, and height; } \\
\text { fasting glucose }>100 \mathrm{mg} / \mathrm{dL} \text {; or use of DM } \\
\text { medications }\end{array}$ & Age and sex & $2.5 \mathrm{~kg}$ & 5 \\
\hline $\begin{array}{l}\text { Briskiewicz } \\
\text { et al. (20) }\end{array}$ & $\begin{array}{l}\text { Brazil } \\
(2018)\end{array}$ & $35-74$ & $\begin{array}{l}\text { Female } \\
(0 / 6,872)\end{array}$ & Cross-sectional & $\begin{array}{c}6,872 \\
(\mathrm{NA})\end{array}$ & LBW & $\begin{array}{c}\text { OR, } 1.28 \\
(1.24-1.45)\end{array}$ & $\begin{array}{l}\text { Having at least three of the following } \\
\text { components based on the National Cholesterol } \\
\text { Education Program Adult Treatment Panel III } \\
\text { updated guidelines: high waist circumference; } \\
\text { high blood glucose; low HDL cholesterol; } \\
\text { hypertriacylglycerolemia; and hypertension }\end{array}$ & $\begin{array}{l}\text { Age, race/skin color, education, PA, } \\
\text { smoking, alcohol consumption, } \\
\text { relative leg length, age at } \\
\text { menarche, and BMl at the age of } \\
20 \text { years }\end{array}$ & $2.5 \mathrm{~kg}$ & 6 \\
\hline $\begin{array}{l}\text { dos Santos } \\
\text { Alves Pde } \\
\text { et al. (14) }\end{array}$ & $\begin{array}{l}\text { Brazil } \\
(2015)\end{array}$ & $10-20$ & Both $(64 / 108)$ & Cohort & $\begin{array}{c}172 \\
(7)\end{array}$ & LBW & $\begin{array}{c}\text { OR, } 0.77 \\
(0.18-3.33)\end{array}$ & $\begin{array}{l}<16.0 \text { years: WC } \geq 90 \text { th percentile; high } \\
\text { triglycerides } \geq 1.7 \mathrm{mmmo} / \mathrm{L} ; \text { low } \mathrm{HDL}-\mathrm{C}<1.03 \\
\mathrm{mmol} / \mathrm{L} \text {; blood pressure } \geq 130 / 85 \mathrm{~mm} \mathrm{Hg} \text {, or } \\
\text { treatment of previously diagnosed } \\
\text { hypertension; fasting glucose } \geq 5.6 \mathrm{mmol} / \mathrm{L} ; \text { or } \\
\text { previously diagnosed type } 2 \mathrm{DM} \text {; age } 16-20 \\
\text { years: } \mathrm{WC} \geq 90 \mathrm{~cm} \text { for South American men } \\
\text { and } \geq 80 \mathrm{~cm} \text { for South American women, } \\
\text { according to the national consensus; elevated } \\
\text { triglycerides } \geq 1.7 \mathrm{mmol} / \mathrm{L} ; \text { reduced } \mathrm{HDL}-\mathrm{C} \text {, } \\
<1.03 \mathrm{mmol} / \mathrm{L} \text { for men and }<1.29 \mathrm{mmo} / \mathrm{L} \text { for } \\
\text { women; blood pressure } \geq 130 / 85 \mathrm{~mm} \mathrm{Hg} \text {, or } \\
\text { treatment of previously diagnosed } \\
\text { hypertension; fasting glucose } \geq 5.6 \mathrm{mmo} / \mathrm{L} \text {; or } \\
\text { previously diagnosed type } 2 \mathrm{DM}\end{array}$ & Crude & $2.5 \mathrm{~kg}$ & 5 \\
\hline
\end{tabular}




\begin{tabular}{|c|c|c|c|c|c|c|c|c|c|c|c|}
\hline References & $\begin{array}{l}\text { Country } \\
\text { (year) }\end{array}$ & $\begin{array}{c}\text { Age } \\
\text { (years) }\end{array}$ & $\begin{array}{l}\text { Sex } \\
\text { (male/female) }\end{array}$ & Study design & $\begin{array}{l}\text { Participants } \\
\text { (cases) }\end{array}$ & $\begin{array}{l}\text { Perinatal } \\
\text { risk factors }\end{array}$ & $\begin{array}{l}\text { OR or RR } \\
(95 \% \mathrm{Cl})\end{array}$ & Definition of metabolic syndrome & Adjustment for covariates & $\begin{array}{l}\text { Cutoff } \\
\text { value }\end{array}$ & NOS \\
\hline Xiao et al. (24) & $\begin{array}{l}\text { China } \\
\text { (2010) }\end{array}$ & $59.3 \pm 8.1$ & $\begin{array}{l}\text { Both } \\
(990 / 1,029)\end{array}$ & Cohort & $\begin{array}{l}2,019 \\
(515)\end{array}$ & LBW & $\begin{array}{c}\text { OR, } 1.66 \\
(1.18-2.34)\end{array}$ & $\begin{array}{l}\text { Presence of three of the following five } \\
\text { components: fasting glucose of at least } 110 \\
\mathrm{mg} / \mathrm{dL} \text { or diagnosed DM; elevated blood } \\
\text { pressure or history of hypertension; serum } \\
\mathrm{HDL}-\mathrm{C} \text { concentration }<40 \mathrm{mg} / \mathrm{dL} \text { for men and } \\
<50 \mathrm{mg} / \mathrm{dL} \text { for women; serum triglyceride } \\
\text { concentration of at least } 150 \mathrm{mg} / \mathrm{dL} \text {; a waist } \\
\text { circumference of at least } 102 \mathrm{~cm} \text { for men and at } \\
\text { least } 88 \mathrm{~cm} \text { for women }\end{array}$ & $\begin{array}{l}\text { Sex, age, central obesity, smoking } \\
\text { status, alcohol intake, hypertension, } \\
\text { dyslipidemia, family history of DM, } \\
\text { occupational status, current social } \\
\text { class, gestational age, and } \\
\text { gestational hypertension }\end{array}$ & $2.5 \mathrm{~kg}$ & 6 \\
\hline $\begin{array}{l}\text { Jornayvaz } \\
\text { et al. }(21)\end{array}$ & $\begin{array}{l}\text { Switzerland } \\
\text { (2016) }\end{array}$ & $50.2 \pm 10.1$ & $\begin{array}{l}\text { Female } \\
(0 / 1,458)\end{array}$ & Cross-sectional & $\begin{array}{l}1,458 \\
(210)\end{array}$ & LBW & $\begin{array}{l}\text { OR, } 1.75 \\
(1.15-2.68)\end{array}$ & $\begin{array}{l}\text { Central obesity, raised triglycerides, reduced } \\
\text { HDL-C, raised blood pressure, raised fasting } \\
\text { plasma glucose level }\end{array}$ & Age, smoking status, and PA & $2.5 \mathrm{~kg}$ & 6 \\
\hline $\begin{array}{l}\text { Jornayvaz } \\
\text { et al. (21) }\end{array}$ & $\begin{array}{l}\text { Switzerland } \\
\text { (2016) }\end{array}$ & $49.7 \pm 9.9$ & Male $(1,088 / 0)$ & Cross-sectional & $\begin{array}{l}1,088 \\
(276)\end{array}$ & LBW & $\begin{array}{c}\text { OR, } 0.96 \\
(0.52-1.76)\end{array}$ & $\begin{array}{l}\text { Central obesity, raised triglycerides, reduced } \\
\text { HDL-C, raised blood pressure, raised fasting } \\
\text { plasma glucose }\end{array}$ & Age, smoking status, and PA & $2.5 \mathrm{~kg}$ & 6 \\
\hline $\begin{array}{l}\text { Balasuriya } \\
\text { et al. (26) }\end{array}$ & $\begin{array}{l}\text { Norway } \\
\text { (2018) }\end{array}$ & $\begin{array}{c}26.4 \pm 0.6 \\
26.5 \pm 0.4\end{array}$ & Both (60/68) & Cohort & $\begin{array}{l}128 \\
(12)\end{array}$ & LBW & $\begin{array}{l}\text { OR, } 1.92 \\
(0.64-5.72)\end{array}$ & $\begin{array}{l}\text { Having any three of the following: central obesity } \\
\text { (WC } \geq 94 \mathrm{~cm} \text { in men and } \geq 80 \mathrm{~cm} \text { in women); } \\
\text { triglycerides } \geq 1.7 \mathrm{mmol} / \mathrm{L} ; \mathrm{HDL} \text { cholesterol } \\
<1.03 \mathrm{mmol} / \mathrm{L} \text { in men, }<1.29 \mathrm{mmol} / \mathrm{L} \text { in women, } \\
\text { or on treatment for these dyslipidemias; blood } \\
\text { pressure } \geq 130 / 85 \mathrm{~mm} \mathrm{Hg} \text {, or on treatment for } \\
\text { hypertension; fasting plasma glucose } \geq 5.6 \\
\text { mmol/L, previously diagnosed type } 2 \mathrm{DM} \text { or on } \\
\text { treatment for DM }\end{array}$ & Crude & $1.5 \mathrm{~kg}$ & 5 \\
\hline $\begin{array}{l}\text { Sipola- } \\
\text { Leppänen } \\
\text { et al. (25) }\end{array}$ & $\begin{array}{l}\text { Finland } \\
\text { (2015) }\end{array}$ & $\begin{array}{l}\text { Exposed: } \\
23.1 \pm 1.4 \\
\text { unexposed: } \\
23.6 \pm 1.1\end{array}$ & $\begin{array}{l}\text { Both } \\
\text { (233/245) }\end{array}$ & Cohort & $\begin{array}{l}478 \\
(27)\end{array}$ & $\begin{array}{l}\text { Premature } \\
\text { birth }\end{array}$ & $\begin{array}{l}\text { OR, } 4.60 \\
(1.90- \\
11.10)\end{array}$ & $\begin{array}{l}\text { Three or more of the following five criteria had to } \\
\text { be met: central obesity }(W C \geq 94 \mathrm{~cm} \text { in men and } \\
\geq 80 \mathrm{~cm} \text { in women); triglycerides } \geq 1.7 \mathrm{mmol} / \mathrm{L} \text {; } \\
\mathrm{HDL}-\mathrm{C} \text { level }<1.03 \mathrm{mmol} / \mathrm{L} \text { in men and }<1.29 \\
\mathrm{mmol} \text { in women; blood pressure } \geq 130 / 85 \mathrm{~mm} \\
\mathrm{Hg} \text {; and fasting plasma glucose level } \geq 5.6 \\
\mathrm{mmol} / \mathrm{L} \text { or type } 2 \mathrm{DM}\end{array}$ & $\begin{array}{l}\text { Sex, age, cohort, parental } \\
\text { educational level, maternal smoking } \\
\text { during pregnancy, birth weight } \\
\text { standard deviation score, and } \\
\text { parental hypertension, DM, } \\
\text { myocardial infarction/stroke, } \\
\text { self-reported PA, and daily smoking }\end{array}$ & $\begin{array}{l}34 \text { and } \\
37 \\
\text { weeks }\end{array}$ & 6 \\
\hline $\begin{array}{l}\text { Catov et al. } \\
\text { (27) }\end{array}$ & $\begin{array}{l}\text { USA } \\
\text { (2016) }\end{array}$ & $\begin{array}{l}\text { Preterm: } \\
23(20-26) \\
\text { term: } \\
24(21-27)\end{array}$ & $\begin{array}{l}\text { Women } \\
(0 / 1,205)\end{array}$ & Cohort & $\begin{array}{l}1,205 \\
(315)\end{array}$ & $\begin{array}{l}\text { Premature } \\
\text { birth }\end{array}$ & $\begin{array}{l}\text { HR: } 1.41 \\
(1.13-1.77)\end{array}$ & $\begin{array}{l}\text { Three out of the following five factors had to be } \\
\text { met: WC }>88 \mathrm{~cm} \text {; fasting triglycerides } \geq 150 \\
\mathrm{mg} / \mathrm{dL} \text {; HDL-C }<50 \mathrm{mg} / \mathrm{dL} \text {; blood pressure } \\
\geq 130 / 85 \mathrm{~mm} \mathrm{Hg} \text { and/or on antihypertensive } \\
\text { medication; and fasting glucose } \geq 100 \mathrm{mg} / \mathrm{dL} \\
\text { and/or treatment with DM medication }\end{array}$ & $\begin{array}{l}\text { Blood pressure, WC, triglycerides, } \\
\text { glucose, } \mathrm{HDL} \text { cholesterol, age, race, } \\
\text { education, baseline BMI, parous at } \\
\text { baseline, smoking at baseline, } \\
\text { time-varying parity, time-varying } \\
\text { exposure to gestational DM or } \\
\text { hypertensive disorders of pregnancy, } \\
\text { and time-varying weight gain }\end{array}$ & $\begin{array}{c}37 \\
\text { weeks }\end{array}$ & 7 \\
\hline $\begin{array}{l}\text { Ramirez-Velez } \\
\text { et al. (18) }\end{array}$ & $\begin{array}{l}\text { Colombia } \\
(2017)\end{array}$ & $9-17.9$ & $\begin{array}{l}\text { Both } \\
(1,134 / 1,376)\end{array}$ & Cross-sectional & $\begin{array}{l}2001 \\
(\mathrm{NA})\end{array}$ & $\begin{array}{l}\text { Premature } \\
\text { birth }\end{array}$ & $\begin{array}{c}\mathrm{OR}, 0.86 \\
(0.52-1.42)\end{array}$ & $\begin{array}{l}\text { At least three of the following five criteria: TG } \\
\geq 100 \mathrm{mg} / \mathrm{dL} ; \mathrm{HDL}-\mathrm{C}<50 \mathrm{mg} / \mathrm{dL}(<45 \mathrm{mg} / \mathrm{dL} \\
\text { for boys aged 9-19 years); fasting glycemia } \\
\geq 110 \mathrm{mg} / \mathrm{dL} ; \mathrm{WC}>75 \text { th percentile for age and } \\
\text { sex; and systolic blood pressure } 90 \text { th percentile } \\
\text { for age, sex, and height }\end{array}$ & $\begin{array}{l}\text { Age, pubertal stage, and weight } \\
\text { status by sex }\end{array}$ & $\begin{array}{c}37 \\
\text { weeks }\end{array}$ & 6 \\
\hline $\begin{array}{l}\text { Darlow et al. } \\
\text { (13) }\end{array}$ & $\begin{array}{l}\text { New } \\
\text { Zealand } \\
\text { (2019) }\end{array}$ & $27-29$ & $\begin{array}{l}\text { Both } \\
(152 / 169)\end{array}$ & Cohort & $\begin{array}{l}321 \\
(50)\end{array}$ & $\begin{array}{l}\text { Premature } \\
\text { birth }\end{array}$ & $\begin{array}{l}\text { OR, } 1.37 \\
(0.75-2.51)\end{array}$ & $\begin{array}{l}\text { Anthropometric measurements, blood pressure, } \\
\text { total body fat, and, following an overnight fast, } \\
\text { standard laboratory tests for plasma glucose and } \\
\text { free insulin, lipid screen, and hemoglobin } A_{1 c}\end{array}$ & Crude & $\begin{array}{c}28 \\
\text { weeks }\end{array}$ & 7 \\
\hline
\end{tabular}




\section{Metaregression and Sensitivity Analysis}

To explore the sources of between-study heterogeneity, the univariate metaregression analysis was performed with the covariates of study design, sex, and continent where the study was conducted. However, none of these covariates was a potential source of between-study heterogeneity. After excluding one study in the analysis of premature birth and metabolic syndrome (OR $>3.0$ ) (22), which included relatively younger subjects, and few individuals met the definition of metabolic syndrome, the pooled result was changed to significant association $(\mathrm{OR}=1.30 ; 95 \% \mathrm{CI}$, $\left.1.04-1.62 ; I^{2}=9.5 \%, P_{\text {heterogeneity }}=0.345\right)$.

In the influence analysis, the pooled ORs (95\% CIs) of the association between LBW and the risk of metabolic syndrome ranged from 1.33 (95\% CI, 1.12-1.57) to 1.48 (95\% CI, 1.24-1.76). The individual study did not have an excessive influence on the pooled ORs.

\section{Small-Study Effect Evaluation}

The visual inspection of the funnel plot (Figure 5) and Egger test $(P=0.286)$ showed no evidence of significant small-study effect for the association between LBW and the risk of metabolic syndrome. No evidence of significant small-study effect in terms of the association between premature birth and the risk of metabolic syndrome was found (Egger test: $P=0.693$ ).

\section{DISCUSSION}

This meta-analysis assessed the association of LBW and premature birth with the risk of metabolic syndrome. The results of the meta-analysis indicated that LBW might increase the risk of metabolic syndrome. In the subgroup analysis by study design, a significantly positive association was found in both cohort and cross-sectional studies. The pooled ORs did not indicate a statistically significant association between preterm birth and the risk of metabolic syndrome. However, the subgroup analysis by study design indicated that premature birth might be associated with an increased risk of metabolic syndrome in the cohort studies. The pooled WMD suggested a significant association between LBW or preterm and higher HOMA-IR, which is widely used in clinical and epidemiological studies to evaluate insulin sensitivity. Insulin resistance is associated with impaired glucose metabolism, increased vascular resistance, atherogenic dyslipidemia, and adipose tissue dysfunction, even before the onset of type 2 diabetes, atherosclerosis, or hypertension.

A previous meta-analysis that included 27 studies found no significant differences between preterm and term-born for the majority of outcomes associated with the metabolic syndrome, whereas preterm birth was associated with higher blood pressure in adult life (37). Moreover, Markopoulou et al. (38) conducted a meta-analysis on 43 studies and suggested that preterm birth was strongly associated with several components of metabolic syndrome and cardiovascular disease in adult life. However, these two meta-analyses investigated the associations of preterm with the components of the metabolic syndrome (38). In addition, a meta-analysis conducted by Silveira and Horta (39) found LBW was associated with an increased risk of metabolic syndrome in adults, whereas the potential impact of premature on the risk of 
TABLE 2 | Summary risk estimates of the association of LBW and premature with the risk of metabolic syndrome.

\begin{tabular}{|c|c|c|c|c|c|c|}
\hline & Subgroup & No. of studies & Pooled OR (95\% Cl) & $I^{2}(\%)$ & $\boldsymbol{P}_{\text {heterogeneity }}$ & $P$-value between subgroups \\
\hline \multirow[t]{12}{*}{ LBW } & All studies & 11 & $1.37(1.17-1.61)$ & 43.6 & 0.060 & \\
\hline & Study design & & & & & \\
\hline & Cohort study & 6 & $1.79(1.39-2.31)$ & 0.0 & 0.712 & 0.007 \\
\hline & Cross-sectional study & 5 & $1.22(1.04-1.43)$ & 46.1 & 0.115 & \\
\hline & Continent & & & & & \\
\hline & Asia & 3 & $1.66(1.21-2.29)$ & 0.0 & 0.817 & 0.023 \\
\hline & Europe & 5 & $1.69(1.23-2.33)$ & 23.7 & 0.263 & \\
\hline & South America & 3 & $1.18(1.00-1.39)$ & 55.9 & 0.104 & \\
\hline & Gender & & & & & \\
\hline & Both & 7 & $1.37(1.04-1.79)$ & 35.0 & 0.161 & 0.464 \\
\hline & Male & 2 & $1.59(0.58-4.38)$ & 79.7 & 0.026 & \\
\hline & Female & 2 & $1.39(1.06-1.83)$ & 50.7 & 0.154 & \\
\hline \multirow[t]{5}{*}{ Premature } & All studies & 5 & $1.48(1.00-2.21)$ & 62.5 & 0.030 & \\
\hline & After excluding one study $(R R>3.0)$ & 4 & $1.30(1.04-1.62)$ & 9.5 & 0.345 & \\
\hline & Study design & & & & & \\
\hline & Cohort studies & 4 & $1.72(1.12-2.65)$ & 54.5 & 0.086 & 0.043 \\
\hline & Cross-sectional studies & 1 & $0.86(0.52-1.42)$ & NA & NA & \\
\hline
\end{tabular}

$\mathrm{Cl}$, confidence interval; $L B W$, low birth weight; $N A$, not available; $R R$, relative risk.

Study

ID
$\%$

Weight

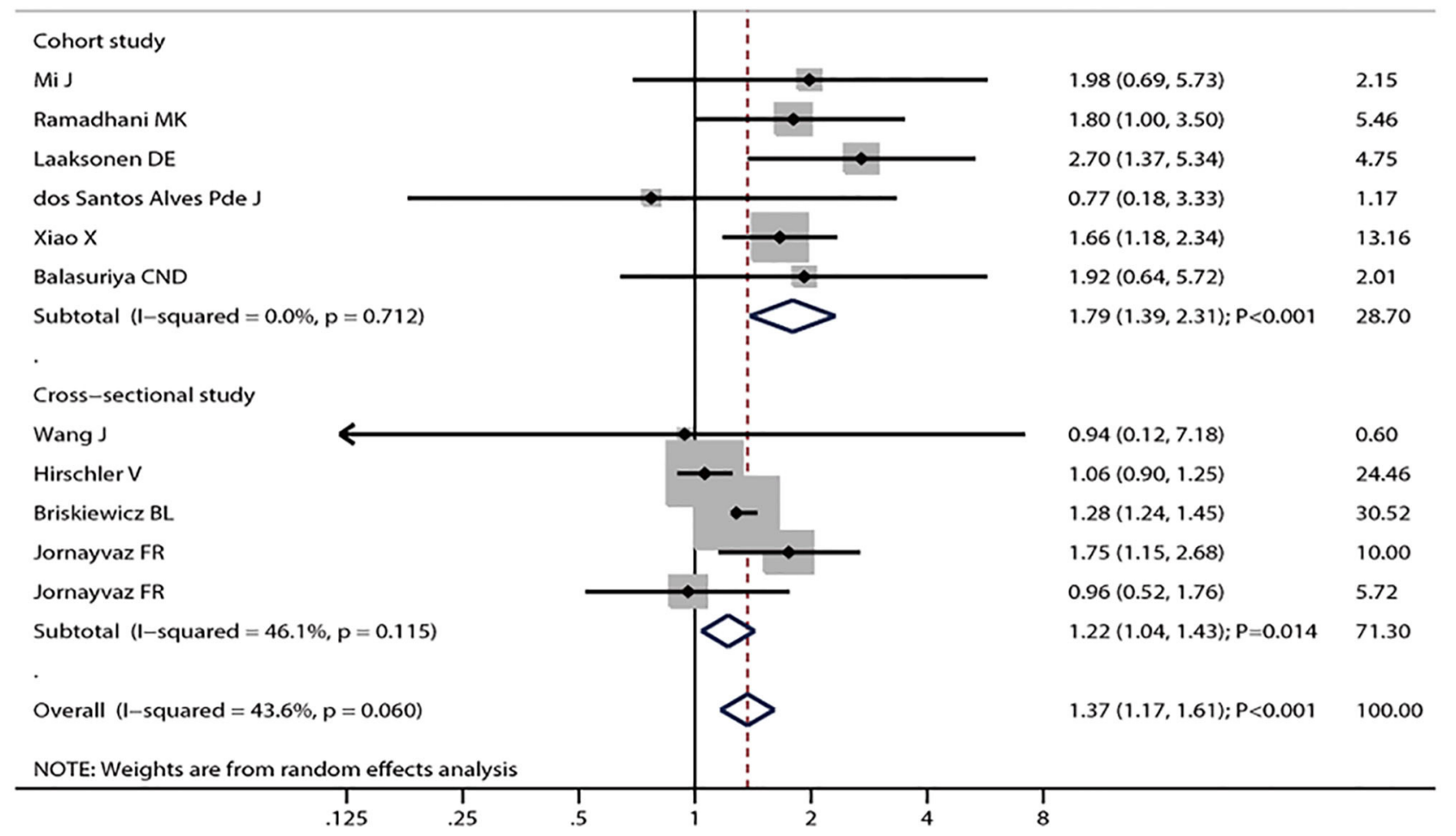

FIGURE 2 | Forest plot of LBW and the risk of metabolic syndrome stratified by the study design. The size of the gray box is positively proportional to the weight assigned to each study, and horizontal lines represent 95\% Cls. 


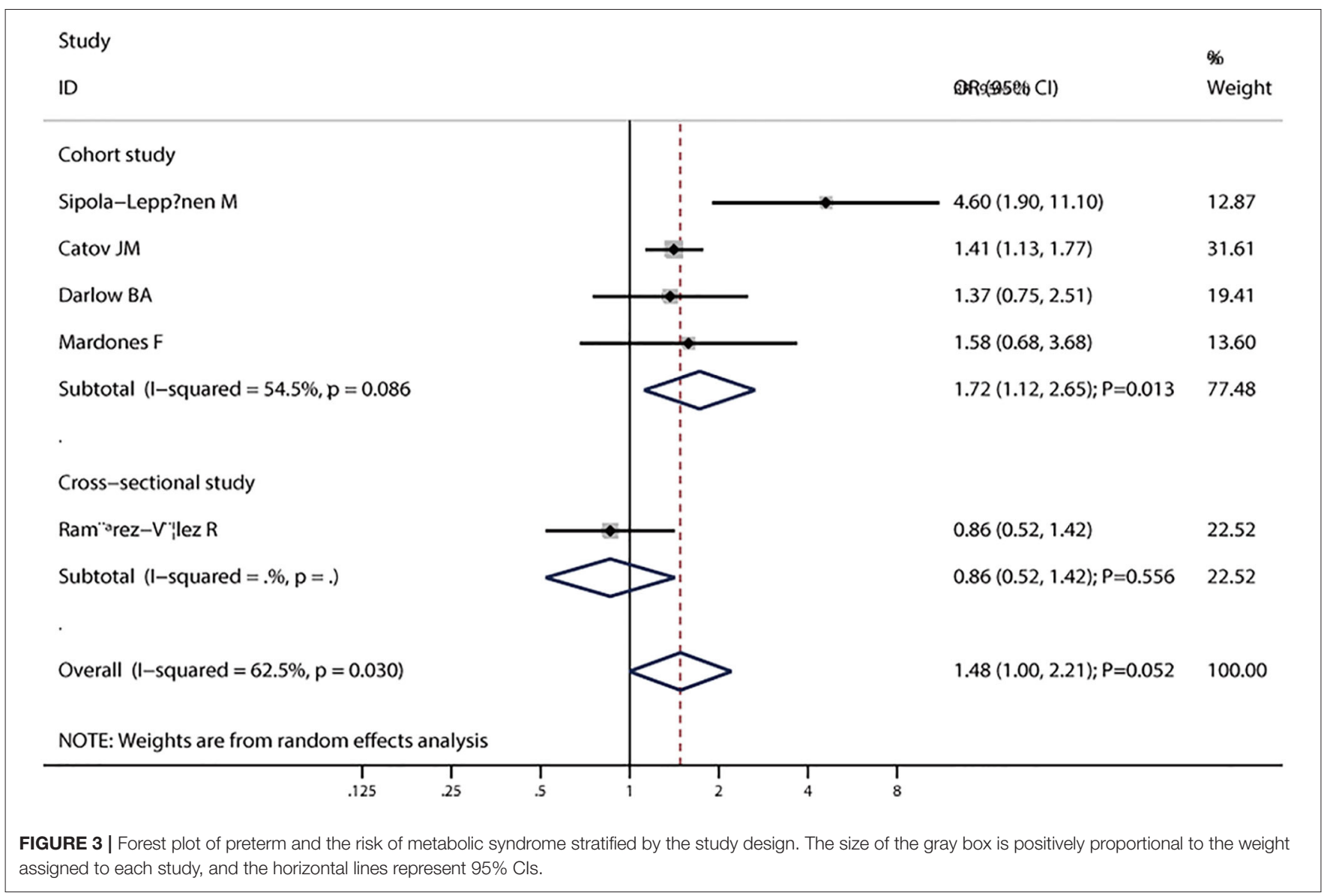

metabolic syndrome was not illustrated. Moreover, the definition of metabolic syndrome differs owing to this study being based on earlier studies. Therefore, the present meta-analysis was conducted from another angle to evaluate the association of preterm or LBW with the risk of metabolic syndrome.

Several biological mechanisms may explain the association of LBW and premature birth with the risk of metabolic syndrome. Low birth weight and premature infants experience in and ex utero growth restriction (40). The later neonatal overfeeding may lead to rapid weight gain, which may be positively related to overweight and elevated blood glucose level (41). The third trimester of pregnancy is the critical period for the kidneys. The development of kidneys after delivery is accelerated for premature infants, and the glomeruli are morphologically abnormal, leading to the development of hypertension later in life (42). The birth weight reflects the intrauterine nutritional status to some extent. Fetal undernutrition has some effect on liver growth. Impaired liver growth may lead to permanent changes in low-density lipoprotein cholesterol metabolism (43).

Between-study heterogeneity is common and needs to be explored in meta-analyses. Moderate between-study heterogeneities were found in this meta-analysis. However, metaregression with covariates of study design, sex, and continent where the study was conducted did not find the source of between-study heterogeneities. After excluding one study (19)
$(\mathrm{OR}>3.0)$ in the analysis of premature birth and the risk of metabolic syndrome, the $I^{2}$ declined to $9.5 \%$, and the conclusion was changed, suggesting that the conclusion was not robust and needed further verification. Moreover, the definition of LBW and preterm differed across included studies, affecting the net effect estimates between LBW or preterm and the risk of metabolic syndrome.

The present meta-analysis had several strengths. First, it was based on a large sample size, and the findings were more robust than those of any individual study. Second, the positive associations remained when cohort studies were pooled, indicating a potential causal relationship. Third, subgroup analysis was conducted with reduced between-study heterogeneity, suggesting that the results were stable.

However, this meta-analysis also had several limitations. First, the number of studies included was insufficient, especially for the analysis of premature birth. Second, the adjusted confounders differed across included studies, which might play an important role in the risk of metabolic syndrome. Third, the information about gestational age and birth weight was obtained through selfreported questionnaires, and it differed across included studies, thus affecting the progression of metabolic syndrome. Fourth, the data on the gestational age of infants in the LBW groups were not available. Hence, whether LBW in a preterm infant had different associations than LBW in a full-term infant could not be 


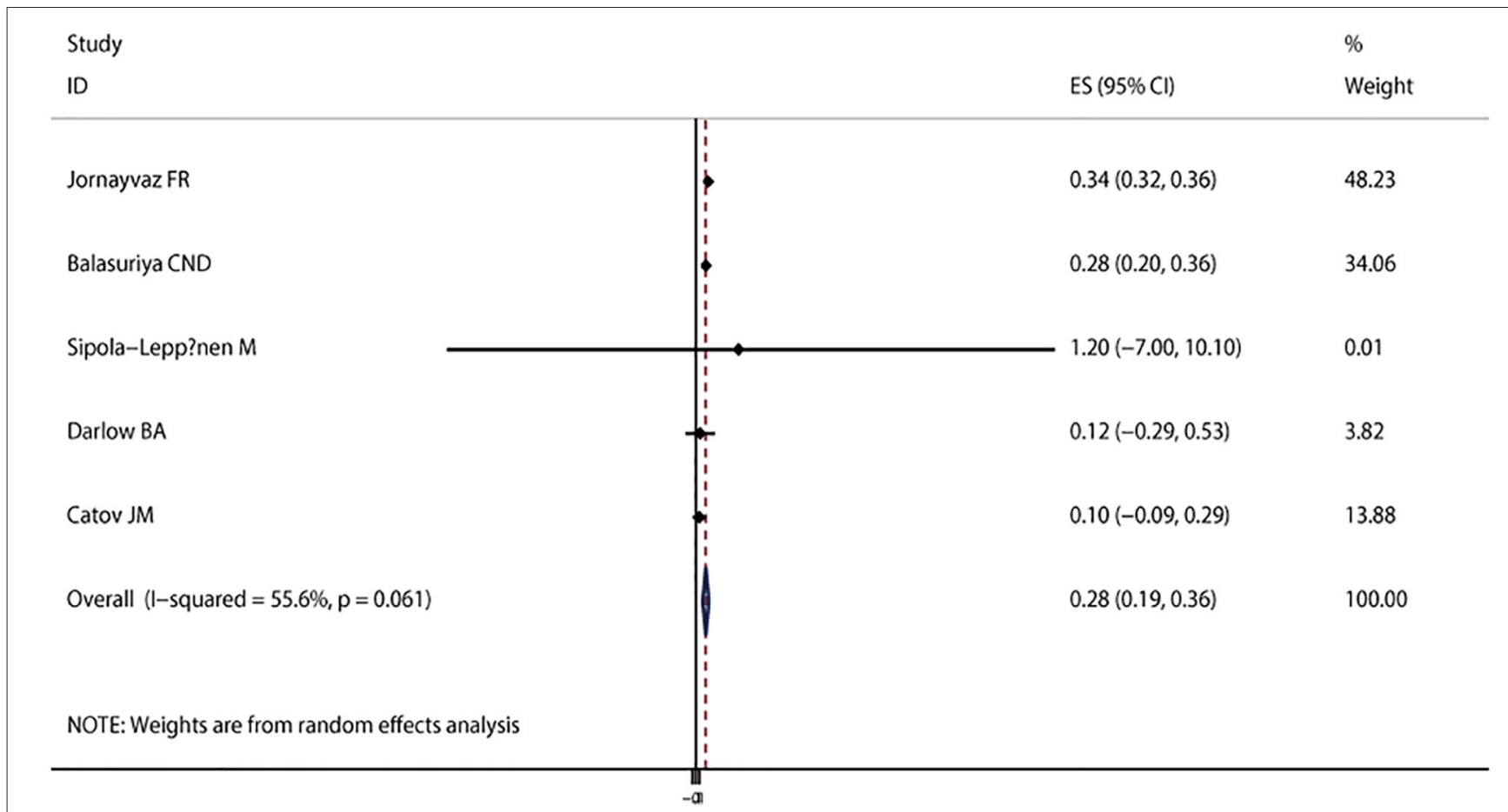

FIGURE 4 | Forest plot of LBW or preterm with the insulin resistance level. The size of the gray box is positively proportional to the weight assigned to each study, and the horizontal lines represent 95\% Cls.

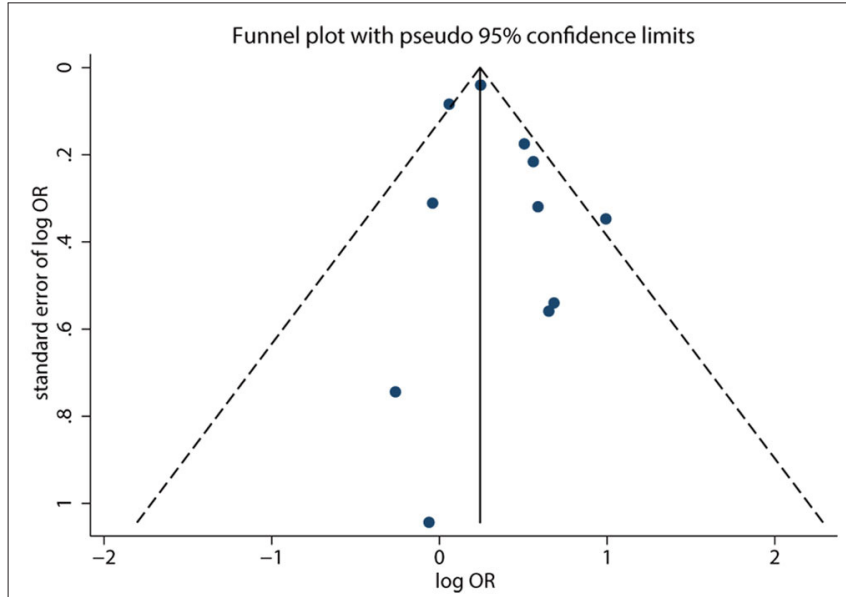

FIGURE 5 | Funnel plot of LBW and the risk of metabolic syndrome. Each dot represents a different study. evaluated. Fifth, the prevalence of metabolic syndrome increased with age, and the outcome assessed at various ages might have biased the results. Sixth, the definition of metabolic syndrome differed across included studies, affecting the effect estimates for the association of LBW and preterm with the risk of metabolic syndrome. Finally, the analysis was at the study level, and individual patient data were not available, which restricted more detailed analysis, including the potential interaction impacts of LBW and preterm.

In conclusion, this meta-analysis suggests that LBW might be a risk factor for metabolic syndrome in childhood and adulthood. Further high-quality studies should be conducted to assess the potential interaction impacts of LBW and preterm on the risk of metabolic syndrome.

\section{DATA AVAILABILITY STATEMENT}

The original contributions presented in the study are included in the article/supplementary material, further inquiries can be directed to the corresponding author.

\section{AUTHOR CONTRIBUTIONS}

LL, YD, and DZ jointly wrote the article and approved the final. All authors contributed to the article and approved the submitted version.

\section{FUNDING}

This work was supported by the National Natural Science Foundation of China (No. 81300555) and Grants from the Fundamental Research Funds for the Central Universities (No. 2042018kf0082). 


\section{REFERENCES}

1. Alberti KG, Zimmet P, Shaw J, Group IDF Epidemiology Task Force Consensus Group. The metabolic syndrome-a new worldwide definition. Lancet. (2005) 366:1059-62. doi: 10.1016/S0140-6736(05)67402-8

2. Zimmet P, Alberti KG, Kaufman F, Tajima N, Silink M, Arslanian S, et al. The metabolic syndrome in children and adolescents - an IDF consensus report. Pediatr Diabetes. (2007) 8:299-306. doi: 10.1111/j.1399-5448.2007.00271.x

3. Expert Panel on Detection, Evaluation, Treatment of High Blood Cholesterol in Adults. Executive summary of the third report of the National cholesterol education program (NCEP) expert panel on detection, evaluation, and treatment of high blood Cholesterol in adults (adult treatment panel III). JAMA. (2001) 285:2486-97. doi: 10.1001/jama.285.19.2486

4. Keskin M, Kurtoglu S, Kendirci M, Atabek ME, Yazici C. Homeostasis model assessment is more reliable than the fasting glucose/insulin ratio and quantitative insulin sensitivity check index for assessing insulin resistance among obese children and adolescents. Pediatrics. (2005) 115:e500-3. doi: 10.1542/peds.2004-1921

5. Reaven GM. Banting lecture 1988. Role of insulin resistance in human disease. Diabetes. (1988) 37:1595-607. doi: 10.2337/diabetes.37.12.1595

6. Friend A, Craig L, Turner S. The prevalence of metabolic syndrome in children: a systematic review of the literature. Metab Syndr Relat Disord. (2013) 11:71-80. doi: 10.1089/met.2012.0122

7. Kassi E, Pervanidou P, Kaltsas G, Chrousos G. Metabolic syndrome: definitions and controversies. BMC Med. (2011) 9:48. doi: 10.1186/1741-7015-9-48

8. Wilson PW, D'Agostino RB, Parise H, Sullivan L, Meigs JB. Metabolic syndrome as a precursor of cardiovascular disease and type 2 diabetes mellitus. Circulation. (2005) 112:3066-72. doi: 10.1161/CIRCULATIONAHA.105.539528

9. Esposito K, Chiodini P, Colao A, Lenzi A, Giugliano D. Metabolic syndrome and risk of cancer: a systematic review and meta-analysis. Diabetes Care. (2012) 35:2402-11. doi: 10.2337/dc12-0336

10. Narain A, Kwok CS, Mamas MA. Soft drink intake and the risk of metabolic syndrome: a systematic review and meta-analysis. Int J Clin Pract. (2017) 71:2. doi: 10.1111/ijcp.12927

11. Oliveira RG, Guedes DP. Physical activity, sedentary behavior, cardiorespiratory fitness and metabolic syndrome in adolescents: systematic review and meta-analysis of observational evidence. PLOS ONE. (2016) 11:e0168503. doi: 10.1371/journal.pone.0168503

12. Tang F, Wang G, Lian Y. Association between anxiety and metabolic syndrome: A systematic review and meta-analysis of epidemiological studies. Psychoneuroendocrinology. (2017) 77:112-21. doi: 10.1016/j.psyneuen.2016.11.025

13. Darlow BA, Martin J, Horwood LJ. Metabolic syndrome in very low birth weight young adults and controls: the New Zealand 1986 VLBW study. J Pediatr. (2019) 206:128-33.e5. doi: 10.1016/j.jpeds.2018. 10.060

14. de Jesus dos Santos Alves P, Henriques ACPT, Pinto LRM, Mota RMS, Alenchar CHM, Alves RS, et al. Endothelial and metabolic disorders in adolescence: low birth weight is not an isolated risk factor. J Pediatr Endocrinol Metab. (2015) 28:407-13. doi: 10.1515/jpem-2014-0146

15. Hirschler V, Bugna J, Roque M, Gilligan T, Gonzalez C. Does low birth weight predict obesity/overweight and metabolic syndrome in elementary school children? Arch Med Res. (2008) 39:796-802. doi: 10.1016/j.arcmed.2008.08.003

16. Mardones F, Arnaiz P, Pacheco P, Dominguez A, Villarroel L, Eriksson JG, et al. Associations of prenatal growth with metabolic syndrome, insulin resistance, and nutritional status in Chilean children. BioMed Res Int. (2014) 2014:472017. doi: 10.1155/2014/472017

17. Mi J, Cheng H, Zhao XY, Zhang ZK, Ding XY, Hou DQ, et al. Ponderal index at birth predicts metabolic syndrome in mid-aged Chinese. Zhonghua Yu Fang Yi Xue Za Zhi. (2004) 38:221-5.

18. Ramirez-Velez R, Correa-Bautista JE, Villa-Gonzalez E, Martinez-Torres J, Hackney AC, Garcia-Hermoso A. Effects of preterm birth and fetal growth retardation on life-course cardiovascular risk factors among schoolchildren from Colombia: the FUPRECOL study. Early Hum Dev. (2017) 106-7:53-8. doi: 10.1016/j.earlhumdev.2017.02.001
19. Wang J, Zhu Y, Cai L, Jing J, Chen Y, Mai J, et al. Metabolic syndrome and its associated early-life factors in children and adolescents: a crosssectional study in Guangzhou, China. Public Health Nutr. (2016) 19:1147-54. doi: 10.1017/S1368980015002542

20. Briskiewicz BL, Barreto SM, do Amaral JF, Diniz M, Molina M, Matos SMA, et al. Early-life nutritional status and metabolic syndrome: gender-specific associations from a cross-sectional analysis of the Brazilian longitudinal study of adult health (ELSA-Brasil). Public Health Nutr. (2018) 21:1546-53. doi: 10.1017/S1368980017004256

21. Jornayvaz FR, Vollenweider P, Bochud M, Mooser V, Waeber G, MarquesVidal P. Low birth weight leads to obesity, diabetes and increased leptin levels in adults: the CoLaus study. Cardiovasc Diabetol. (2016) 15:73. doi: 10.1186/s12933-016-0389-2

22. Laaksonen DE, Lakka HM, Lynch J, Lakka TA, Niskanen L, Rauramaa R, et al. Cardiorespiratory fitness and vigorous leisure-time physical activity modify the association of small size at birth with the metabolic syndrome. Diabetes Care. (2003) 26:2156-64. doi: 10.2337/diacare.26.7.2156

23. Ramadhani MK, Grobbee DE, Bots ML, Castro Cabezas M, Vos LE, Oren A, et al. Lower birth weight predicts metabolic syndrome in young adults: the atherosclerosis risk in young adults (ARYA)-study. Atherosclerosis. (2006) 184:21-7. doi: 10.1016/j.atherosclerosis.2005.03.022

24. Xiao X, Zhang ZX, Li WH, Feng K, Sun Q, Cohen HJ, et al. Low birth weight is associated with components of the metabolic syndrome. Metabolism. (2010) 59:1282-6. doi: 10.1016/j.metabol.2009.12.001

25. Sipola-Leppanen M, Vaarasmaki M, Tikanmaki M, Matinolli HM, Miettola $\mathrm{S}$, Hovi P, et al. Cardiometabolic risk factors in young adults who were born preterm. Am J Epidemiol. (2015) 181:861-73. doi: 10.1093/aje/kwu443

26. Balasuriya CND, Stunes AK, Mosti MP, Schei B, Indredavik MS, Hals IK, et al. Metabolic outcomes in adults born preterm with very low birthweight or small for gestational age at term: a cohort study. J Clin Endocrinol Metab. (2018) 103:4437-46. doi: 10.1210/jc.2018-00464

27. Catov JM, Althouse AD, Lewis CE, Harville EW, Gunderson EP. Preterm delivery and metabolic syndrome in women followed from prepregnancy through 25 years later. Obstetr Gynecol. (2016) 127:1127-34. doi: 10.1097/AOG.0000000000001434

28. Moher D, Liberati A, Tetzlaff J, Altman DG, PRISMA Group. Preferred reporting items for systematic reviews and meta-analyses: the PRISMA statement. PLoS Med. (2009) 6:e1000097. doi: 10.1371/journal.pmed.1000097

29. Stang A. Critical evaluation of the Newcastle-Ottawa scale for the assessment of the quality of nonrandomized studies in meta-analyses. Eur J Epidemiol. (2010) 25:603-5. doi: 10.1007/s10654-010-9491-z

30. Ades AE, Lu G, Higgins JP. The interpretation of random-effects meta-analysis in decision models. Med Decis Making. (2005) 25:646-54. doi: 10.1177/0272989X05282643

31. Higgins JP, Thompson SG, Deeks JJ, Altman DG. Measuring inconsistency in meta-analyses. BMJ. (2003) 327:557-60. doi: 10.1136/bmj.327.7414.557

32. Thompson SG, Higgins JP. How should meta-regression analyses be undertaken and interpreted? Stat Med. (2002) 21:1559-73. doi: 10.1002/sim.1187

33. Altman DG, Bland JM. Interaction revisited: the difference between two estimates. BMJ. (2003) 326:219. doi: 10.1136/bmj.326.7382.219

34. Tobias A. Assessing the influence of a single study in meta-analysis. Stata Tech Bull. (1999) 47:15-7.

35. Egger M, Davey Smith G, Schneider M, Minder C. Bias in metaanalysis detected by a simple, graphical test. BMJ. (1997) 315:629-34. doi: 10.1136/bmj.315.7109.629

36. Wells G. The Newcastle-Ottawa Scale (NOS) for assessing the quality of nonrandomised studies in meta-analyses. (2019). Available online at: https:// www.researchgate.net/publication/288802810_The_Newcastle-Ottawa_ Scale_NOS_for_Assessing_The_Quality_of_Nonrandomised_Studies_in_ Meta-analyses

37. Parkinson JR, Hyde MJ, Gale C, Santhakumaran S, Modi N. Preterm birth and the metabolic syndrome in adult life: a systematic review and meta-analysis. Pediatrics. (2013) 131:e1240-63. doi: 10.1542/peds.2012-2177

38. Markopoulou P, Papanikolaou E, Analytis A, Zoumakis E, Siahanidou T. Preterm birth as a risk factor for metabolic syndrome and cardiovascular disease in adult life: a systematic review and meta-analysis. J Pediatr. (2019) 210:69-80.e5. doi: 10.1016/j.jpeds.2019.02.041 
39. Silveira VM, Horta BL. Birth weight and metabolic syndrome in adults: meta-analysis. Rev Saude Publ. (2008) 42:10-8. doi: 10.1590/S0034-89102008000100002

40. Tinnion R, Gillone J, Cheetham T, Embleton N. Preterm birth and subsequent insulin sensitivity: a systematic review. Arch Dis Childhood. (2014) 99:362-8. doi: 10.1136/archdischild-2013-304615

41. Stettler N, Stallings VA, Troxel AB, Zhao J, Schinnar R, Nelson SE, et al. Weight gain in the first week of life and overweight in adulthood: a cohort study of European American subjects fed infant formula. Circulation. (2005) 111:1897-903. doi: 10.1161/01.CIR.0000161797.67671.A7

42. Sutherland MR, Gubhaju L, Moore L, Kent AL, Dahlstrom JE, Horne RS, et al. Accelerated maturation and abnormal morphology in the preterm neonatal kidney. J Am Soc Nephrol. (2011) 22:1365-74. doi: 10.1681/ASN.2010 121266
43. Barker DJ, Martyn CN, Osmond C, Hales CN, Fall CH. Growth in utero and serum cholesterol concentrations in adult life. BMJ. (1993) 307:1524-7. doi: 10.1136/bmj.307.6918.1524

Conflict of Interest: The authors declare that the research was conducted in the absence of any commercial or financial relationships that could be construed as a potential conflict of interest.

Copyright (c) 2020 Liao, Deng and Zhao. This is an open-access article distributed under the terms of the Creative Commons Attribution License (CC BY). The use, distribution or reproduction in other forums is permitted, provided the original author(s) and the copyright owner(s) are credited and that the original publication in this journal is cited, in accordance with accepted academic practice. No use, distribution or reproduction is permitted which does not comply with these terms. 